\section{Література}

1. Інтенсифікація навчального процесу студентів при вивченні тестових завдань під час практичних занять на клінічних базах / О. В. Громов, П. Г. Герасимчук, М. О. Коваленко, М. В. Василишина // Медична освіта. 2008. - № 2. - C. 11-12.

2. Особливості роботи з іноземними студентами при вивченні госпітальної хірургії / І. О. Гіленко, Д. Г. Дем’янюк,
В. І. Ляховський [та ін.] // Медична освіта. - 2009. - № 1. - С. 27-29.

3. Актуальні аспекти викладання загальної хірургії відповідно до вимог Свропейського освітнього простору / Я. Й. Крижановський, В. С. Кульбака, В. М. Меллін [та ін.] / / Медична освіта. - 2010. - № 1.- С. 52-53.

\title{
ДЕЯКІ АСПЕКТИ КОНСУЛЬТАТИВНОЇ РОБОТИ, ЯКА ПРОВОДИТЬСЯ НА КАФЕДРІ НЕЙРОХІРУРГІЇ І НЕВРОЛОГЇ̈ ОДЕСЬКОГО ДЕРЖАВНОГО МЕДИЧНОГО УНІВЕРСИТЕТУ
}

\author{
А. С. Сон, В. В. Добровольський, Ю. І. Горанський, О. М. Стоянов,
} Н. В. Добровольська

Одеський державний медичний університет

\section{SOME ASPECTS OF CONSULTING WORK CONDUCTING AT THE DEPARTMENT OF NEUROSURGERY AND NEUROLOGY OF ODESSA STATE MEDICAL UNIVERSITY}

\author{
A. S. Son, V. V. Dobrovolskyi, Yu. I. Horanskyi, O. M. Stoyanov, N. V. Dobrovolska \\ Odessa State Medical University
}

\begin{abstract}
У статті представлений аналіз методичних підходів проведення консультативної роботи співробітниками кафедри нейрохірургії і неврології Одеського державного медичного університету та рекомендації щодо підвищення їі якості.

The article presents an analysis of methodological approaches of consultative work by the department of neurosurgery and neurology of Odessa State Medical University and recommendations to improve its quality.
\end{abstract}

Вступ. Під час реформування охорони здоров'я та в період економічної кризи значення консультативної роботи провідних спеціалістів кафедр медичних університетів значно зростає. Сприяє цьому створення лікувальних комплексів, таких як університетська клініка, дистанційно-комунікаційний центр, з допомогою якого можливий зв'язок з лікувальними закладами Південного регіону України.

Підвищення значення консультативної роботи для лікувального процесу обумовлено низкою факторів:

1. На етапі первинної медичної допомоги (в сільській місцевості) не вистачає лікарів, а наприклад в Одеській області в $21 \%$ цих закладів взагалі немає лікаря [1]. У випадку складної клінічної ситуації(черепно-мозкова та спинальнатравма, субарахноїдальний крововилив тощо) життя хворого залежить від досвіду сімейного лікаря, який повинен оперативновизначитись зпопереднім діагнозом та необхідністю транспортування пацієнта до районного центру чи обласного, в яких є високоспеціалізована допомога, відповідно неврологічна в районній та нейрохірургічна в обласній лікарнях [2]. В 2008 році $60 \%$ випускників медичного університету отримали розподілення для роботи в сільській місцевості, з них в селі працюють лише $25 \%$ [3].

2. В Одеській області більше $37 \%$ молодих лікарів 3 досвідом роботи доп'яти років, а 80 \% 3 них працюють 
в сільській місцевості, де можливості проконсультуватися $з$ провідними фахівцями обмежені. Все це може деякою мірою знизити якість лікувального процесу.

3. В білышості клінік, в тому числі в районних лікарнях, покращується устаткування новою апаратурою та комп'ютерною технікою, яка потребує певних навичок при ії використанні. Це обумовлює необхідність консультацій підготовленими фахівцями.

4. Необхідність консультативного виду лікарської допомоги зростає, ще й тому, що в багатьох випадках під типовою клінічної картиною соматичних захворювань маскуються ураження нервової системи (міастенія та міастеноподібні синдроми тощо), та навпаки, декомпенсація хронічних соматичних хвороб (атеросклероз, серцеві аритмії, артеріальна гіпертензія тощо) може стати чинником ураження нервової системи (мозковий інсульт) і потребує консультації невролога сумісно з лікарем іншого фаху [4].

5. Важливість термінової консультації полягає в тому, що для максимальної ефективності подальшого лікування пацієнта важливо провести їі в перші години після госпіталізації [2].

6. В приватних клініках не завжди працюють високопідготовлені лікарі, не проводиться постійна курація пацієнта в процесі лікування, а саме лікування обмежується багатьма вартісними методами обстеження й рекомендаціями використання модних, не завжди патогенетично обгрунтованих лікарських засобів, інколи навіть лише біологічно активних домішок. Лікарі працюють у відриві від колег, з якими могли б порадитись, запобігти або виправити помилки під час лікування складного пацієнта.

7. В зв' язку з соціальним розшаруванням суспільства зростає необхідність безкоштовної якісної консультативної допомоги високого фахового рівня широким верствам населення.

Всі ці фактори обумовлюють необхідність системної роботи консультування молодих лікарів, а також лікарів, які працюють у відриві від великих центрів медичної думки та практики.

Основна частина. На кафедрі нейрохірургії і неврології Одеського державного медичного університету (ОДМУ) приділяється прискіплива увага системній роботі щодо медичного консультування в усіх аспектах нашої професійної діяльності. Ми вважаємо, що розвинення й удосконалення консультативної роботи на сучасному етапі розвитку медицини дасть позитивний результат щодо кращого використання можливостей науково-лікувального потенціалу кафедри. Цій роботі сприяє ряд факторів, які суттєво впливають на результативність консультативної роботи:
1. Ряд організаційних заходів, які впроваджені в ОДМУ, дали можливість більш якісної взаємодії 3 лікарняними базами.

2. Широку дорогу цій роботі дало підпорядкування ОДМУ міської лікарні № 12 п’ ять років тому назад, що дало можливість на іï базі створити перший в Україні лікувально-навчальний комплекс - “Університетську клініку ОДМУ”.

3. В ОДМУ широко впроваджені дистанційні комунікаційні технології, які дають можливість вести роботу в усьому Південному регіоні України.

4. Впровадження в життя наочних посібників, електронної бібліотеки на кафедрі та в університетській бібліотеці.

Основні напрямки лікувально-консультативної роботи, які використовуються на кафедрі нейрохірургії і неврології ОДМУ:

I. Викладачі кафедри основні зусилля спрямовують в неврологічні та нейрохірургічні відділення, на базі яких працює кафедра й проходить практичне викладання курсу нервових хвороб студентам 4-го курсу та нейрохірургії 5-го курсу. Цей вид консультування найбілыш важливий для навчального процесу й потребує високої організації, тому що має складну мету -з'єднати знання та зусилля викладача, лікуючого лікаря й студента.

II. Весь викладацький склад закріплений як куратори за стаціонарними відділеннями (обласна клінічна лікарня, неврологічні та нейрохірургічні відділення міських клінічних лікарень № 1, 11, Університетської клініки ОДМУ, обласний психоневрологічний диспансер). В обласній клінічній лікарні оперативний відділ щоранку до $11^{00}$ приймає заявки, щодо необхідності планової консультації невролога, та доводить до відома співробітників кафедри-кураторів відділень. Це дає можливість проконсультувати лікуючого лікаря стосовно важкого клінічного питання протягом робочого дня, коли консультант і лікуючий лікар знаходяться на робочому місці. Така ж схема існує й в інших лікарнях, де базується кафедра.

Виконання цих вимог дасть можливість забезпечення якісної консультації лікуючого лікаря кафедральним співробітником.

III. Великі можливості відкрилися для викладачів кафедри нейрохірургії і неврології після підпорядкування університету клініки. В Університетській клініці розгорнуті неврологічне, терапевтичне та хірургічні стаціонарні відділення, та, що особливо важливо поліклініка, де найчастіше потрібна консультація невролога. Працівники кафедр мають свої дні та години консультацій, але, як правило, вони відбуваються терміново за необхідністю. 
Недоліки, які найчастіше виникають при проведенні консультації

\begin{tabular}{|c|c|}
\hline $\begin{array}{c}3 \text { боку лікуючого лікаря, який замовляє } \\
\text { консультативну допомогу }\end{array}$ & 3 боку консультанта \\
\hline $\begin{array}{l}\text { 1. Не завжди обгрунтовано необхідність та не } \\
\text { визначена мета консультації }\end{array}$ & \multirow{2}{*}{$\begin{array}{l}\text { 1. Лікар-консультант недостатньо обгрунтовує } \\
\text { діагноз та лікувально-діагностичні рекомендації на } \\
\text { підставі клінічного обстеження хворого }\end{array}$} \\
\hline $\begin{array}{l}\text { 2. Не в повній мірі забезпечено стандартне попереднє } \\
\text { обстеження хворого за виявленим } \\
\text { симптомокомплексом }\end{array}$ & \\
\hline $\begin{array}{l}\text { 3. Не систематично фіксується час подання заявки на } \\
\text { консультацію з визначенням терміновості (ургентна } \\
\text { або планова) }\end{array}$ & \multirow{2}{*}{$\begin{array}{l}\text { 2. В записах лікаря-консультанта не завжди } \\
\text { вказується присутність лікуючого лікаря на } \\
\text { консультації, хоча відповідальність виконання або } \\
\text { обгрунтоване невиконання рекомендацій } \\
\text { покладається на лікуючого лікаря }\end{array}$} \\
\hline $\begin{array}{l}\text { 4. Не завжди лікар, який викликав консультанта, } \\
\text { присутній на консультації свого пацієнта }\end{array}$ & \\
\hline
\end{tabular}

Університетська клініка ОДМУ в силу свого авторитету, який підвищується за рахунок якості надання консультативної допомоги провідними фахівцями клінічних кафедр ОДМУ, приймає хворих з усього Південного регіону України, а також Росії, Молдови, Білорусії.

IV. Значно розширилося коло консультування з введенням в дію консультативного телемедичного цен- тру, що дає можливість працювати з молодими лікарями в усій Одеській області, а також брати участь в телеконференціях, обговоренні та вирішенні проблем в складних клінічних випадках, як за графіком, так і терміново. Відмічається зростання частки ургентних консультацій співробітників кафедри нейрохірургії і неврології за останні три роки 326 до $41 \%$ (див. діаграми).

Динаміка змін співвідношення ургентних та планових консультацій співробітниками кафедри стаціонарних відділень обласної клінічної лікарні за останні три роки

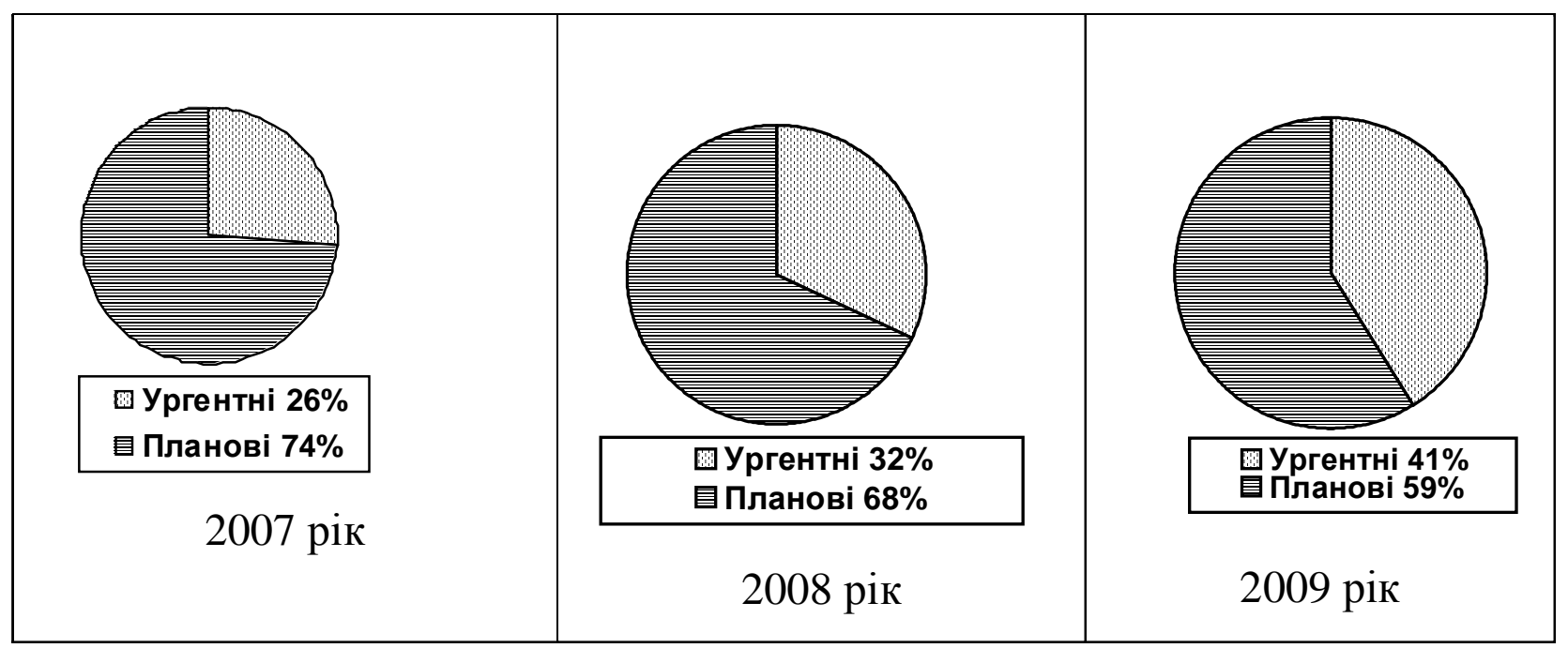

V. Як провідні фахівці, викладачі кафедри систематично беруть участь у бригадних виїздах в райони Одеської області, ведуть широку санітарно-просвітницьку діяльність.

VI. Важливуувагу викладачікафедри приділяють консультуванню в лікарнях міста, як планово, так і терміново. Але ця робота потребує удосконалення в силу різних організаційних чинників та різноїпідпорядкованості.

VII. Кафедрою нейрохірургії і неврології в Одесі проводиться неврологічна школа Європейської федерації неврологічних товариств (EFNS) для молодих спеціалістів у галузі нервових хвороб.
Висновки. Значення лікарського консультування в сучасних умовах неухильно зростає. Відмічається прогресивне зростання частки ургентних консультацій співробітниками кафедри, що свідчить про затребуваність високопрофесійного фахового рівня викладацького складу кафедри в повсякденній практичній роботі лікарів багатопрофільного стаціонару та активну інтеграцію науково-педагогічної та лікувальної роботи.

Необхідна комплексна робота кафедри, університету для того, щоб в повній мірі використовувати величезний науково-практичний потенціал фахівців кафедр ОДМУ. 